\title{
Where Are We Going? \\ Attitudes Towards Migrations in Archaeological Thought
}

\author{
Kerstin Cassel
}

\begin{abstract}
Migrations have always been a much debated topic in archaeology. In the first half of the $20^{\text {th }}$ century migrations were a common explanation for change in the material culture, but they were also used in a nationalistic and chauvinistic way. After the Second World War a reaction came and many archaeologists rejected migrations as a relevant explanation, whereby migrations more or less disappeared from the archaeological discourse. Such changes in the archaeological interest could be linked to public opinions of the times, as well as to reactions within the discipline. In conclusion it is argued that a discussion about past migrations is important, not least in order to question prevailing ideas about a cultural homogeneity or "pureness" in the past.
\end{abstract}

Kerstin Cassel, Department of Archaeology, Stockholm University, SE10691 Stockholm, Sweden.

"If we rethink culture and its science, anthropology, in terms of travel, then the organic, naturalizing bias of the term culture - seen as a rooted body that grows, lives dies, etc - is questioned. Constructed and disputed historicities, sites of displacement, interference, and interaction, come more sharply into view" (Clifford 1992:101).

In all times people have left their homes in search of new places to live. Their reasons vary - they might be refugees, adventurers or colonizers - but they are all on the move, and on their journey they will meet other people, cultures and places. People who leave their home for the unknown are often associated with heroism, and special notions are linked to such movements (Helms 1998). It is also common that a people's myth of origin includes a migration in the past, which ties the group together and strengthens their feeling of a common identity (e.g. Eriksen, 1993; Howe 1989).

Migrations have been an important and much debated phenomenon in archaeology as well. In the early days of archaeology, they were seen as an unproblematic and natural part of the appearance and change of a culture, whereas the processual archaeology more or less rejected migrations as a relevant subject of archaeological study. Today the question has once again come up for discussion, something that most likely is related to the great interest in ethnicity and cultural identity (e.g. Jenkins 1997; Jones 1997; Pohl 1998).

The main theme of the following discussion is how migrations have been used in the history of archaeology, and whether (and how) those archaeological perspectives are connected with the general opinions of the 
times. This latter question should not be carried too far, since science tends to go its "own way" with reactions against old research and paradigmatic shifts. But it is an important question to debate, not least because immigration is a phenomenon which is intensively discussed in our own time. To take a closer look at archaeological theories and their relation to our own time is essential if we want to observe how archaeology is used in the public debate.

\section{THE CONCEPT OF "MIGRATION"}

"In the history of archaeology, questions concerning ancient migrations have always been of immediate interest. The difference between the answers indicates the dividing line between different theoretical traditions and generations of researchers" (editor's introduction to the discussion about migration in Fornvännen 1955:1, my transl.).

It is interesting to note that the mere mention of "migrations" is enough to invoke a reaction and opposition among many archaeologists. This is probably due to an association with the traditional view on migrations, and the fact that migrations often were used as a more or less "standard" answer as to why cultures changed. But the migration theories of today, in disciplines like sociology and history, are quite different from this, and people's movements are studied in a number of ways. This is not the place to discuss the big question of which movements of people are to be called "migrations"; it is enough to establish the fact that the theoretical debate of today groups many different courses of events under the concept (Cohen 1996). Titles like "Traveling Cultures" (Clifford 1992) and "Cultures in Conflict" (Bitterli 1989) illustrate the interest in people's movements and the cultural meetings and clashes they cause. Consequently, it should be noted that migration is a highly variable concept, which not least is shown by the history of archaeological thought.
One telling example of such changes is the question of a people's origin, their $U r$ heimat (Kossinna 1978; Oxenstierna 1948; Tunberg 1940), or who were the first settlers of an area (Eriksen 1996). In this debate migrations naturally had a large part. The change in today's debate on indigenous peoples (Sw. ursprungsbefolkning) is evident, even if there is a tendency in the public debate to mix up indigenous people with the first inhabitants. In the United Nations "International Labour Organisation Convention Concerning Indigenous and Tribal Peoples in Independent Countries" (ILO Convention 169), there is no mention of "first settlers". Instead the Convention applies to people who inhabited the area at the time of colonisation or the establishment of present state boundaries. Consequently, today's debate on indigenous people does not have to focus on the question of who were the first inhabitants.

Within archaeology people's movements and wanderings have usually been associated with whole populations or large groups. The focus is on invasions and conquests, which cause a migration. "The overwhelming majority of archaeologists' theories involve the movement of whole peoples, or in other words, society-level migrations - precisely the kind that have occurred least frequently in the course of recorded history" (Adams et al. 1978:489). In anthropology one can notice a change during the $20^{\text {th }}$ century, and today the individual is the focus of attention. "Thus there developed an approach which saw the individual, as the bearer of culture, rapidly transported into a new cultural milieu where he as an individual has to sort out experience and come into some successful adaptation given both the nature of his background and his new environment" (Kasdan 1970:3). The change in anthropologists' interest is almost certainly connected with changes in the contemporary society. In the $20^{\text {th }}$ century one could observe that people had quite different motives for their migrations, not least to find work and seek one's fortune somewhere else. 
The primary interest in the study of migration could thus be described as having changed from the collective to the individual. But of course the debate was also influenced by catastrophes such as war and famine, which resulted in large movements and which the media have often paid a lot of attention to. However, the shift towards the individual has brought with it completely new questions, and the fact that archaeology has not been greatly influenced by this approach is probably due to the character of the source material, in which it is hard to identify the individual. But the reaction against the older research has unfortunately led to a rejection of the study of migrations on the whole in archaeology, even though it is clear that different types of movements have occurred in all times.

The definition of migration is thus variable, but my impression is that archaeologists have a comparatively narrow definition of what constitutes a migration. In the anthropological study of migration one discusses for instance the consequences of slavery (e.g. Rawick 1970), but the ancient trade in humans, like prisoners of war, has not been treated or conceived of as migration in archaeology. But the difference between archaeology and anthropology is above all that the latter has moved from an approach where migrations are something unnatural and problematic, towards a conception where migrations are a normal and frequent occurrence (Kasdan 1970:4). This is important because it implies the possibility of using general theories instead of special theories for migrations.

It is also important to be aware that the meaning-content of the concept "migration" is not only dependent on the definition. The meaning of the concept depends to a great extent on our valuations, which will influence how we use it in archaeological contexts as well. In the public debate one can note a difference between "us" and "them" when it comes to migrations. When "other" people are on the move it is often seen as a threat, and we tend to belittle people from other cultures when they migrate, for instance by calling them "economical refugees" and by doing so questioning their right to move. We hardly regard it like that when directors, engineers or sport stars in the West move to improve their economical conditions. People who emigrate from our country are regarded as enterprising and qualified, and one talks about "brain drain", that is, educated people who seek somewhere else to live and work. Consequently, for the interpretation, it is of significance who is migrating, and this includes interpretations done by archaeologists as well. This can be compared to the typology and classification of migrations where the starting point has been a division into "high" (giving) and "low" (receiving) cultures, a division which has been criticized in later years (Petersen 1996; Richmond 1996).

\section{EVOLUTION AND MIGRATION}

"[The journeys of the Vikings] could be regarded as the last waves of the Great Migrations, which at first seemed to have washed away the whole classical cultivation, but which at second glance appeared to have sowed the seeds for a more beautiful future than the one that the decrepit Roman World could have created" (Montelius 1919:299, my transl.).

For a long time one did not see migrations as a problem in archaeology, and distinguished researchers like V. Gordon Childe "attributed nearly every major cultural development of the Neolithic and Bronze Ages to a movement of peoples, usually from the east" (Adams et al. 1978:493). But even if migrations had been an accepted explanation within the traditional archaeology, it is a mistake to assume that one understood the concept in the same way through all time. On the other hand, by looking closer at the theories of migration, it is possible to reach an understanding of the underlying theories of human 
nature and political currents in archaeology.

Archaeology is closely related to the modernist project, and one often tends to consider modernism as a homogeneous set of ideas. In some respects this is unfortunate, because it makes us view modern man as something quite different from the earlier pre-modern man (and perhaps also different from today's postmodern man). Within the modernist project there are various theories and conceptions, and the ideas of the Enlightenment have changed over time. When I reflect upon the different approaches to migration and their theoretical background, I often find that they are linked to the outlook on mankind. In his book on modernity's history of ideas, Sven-Eric Liedman (1997) describes how two opposite trends - universalistic and particularistic ideas - often meet each other and sometimes even exist side by side. The uni-

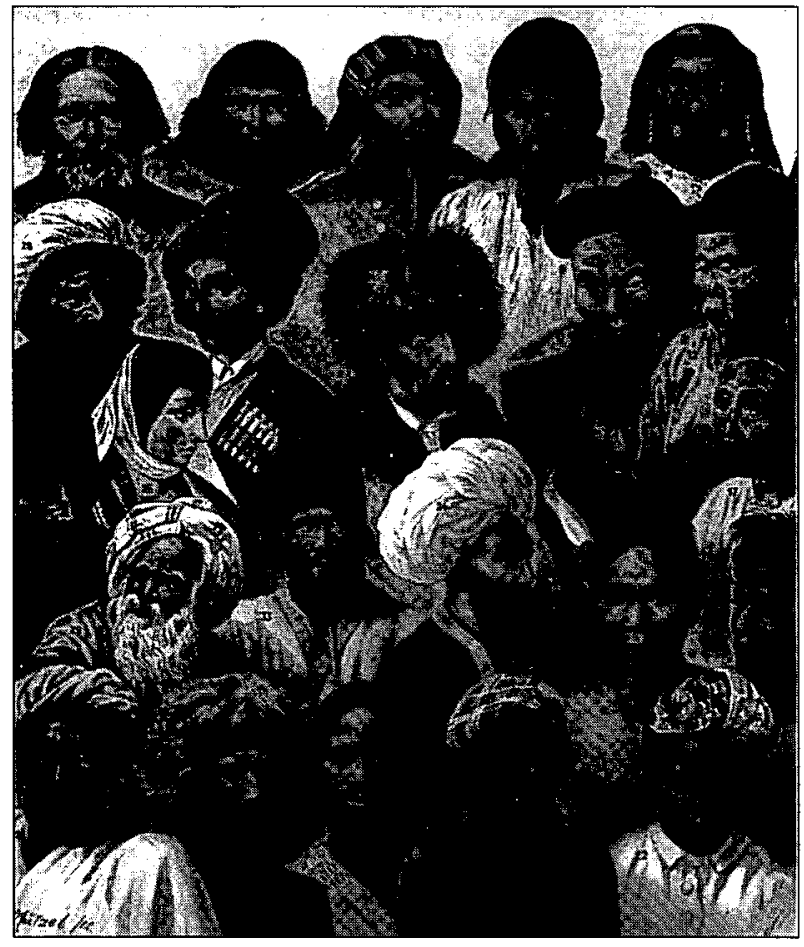

Fig. 1. Ideas about race are often based on both biological and cultural characteristics, and it could be difficult to separate them. In this illustration from a Swedish encyclopaedia, the colour of skin and features are accentuated, as well as dress and beard style (Liedman 1997:130). versalistic approach views all

humans as psychologically equal and with the same intelligence. But even though humans were thought to be essentially the same all over the world, it was Western Europe which constituted the ideal. Every person on earth could look forward to a progress towards the European civilization (Liedman 1997:143; Trigger 1989:57).

In Europe the middle class embraced the early ideas of the Enlightenment (with a principally universalistic approach), due to the fact that one regarded the society and the industrial revolution as a natural development of mankind. White Americans shared this optimistic view, but they were not willing to apply it to the natives as well. The latter people were considered to be an exception, and because of their presumed biological deficiency they could not take advantage of the European progress (Trigger 1989:109f). Consequently the universalistic perspective on mankind was weakened, and by the end of the $18^{\text {th }}$ century one could see the appearance of racism that was linked to a hierarchic approach, in which one advocated that the different races should be kept apart (Liedman 1997:162f). These thoughts were supported by a strong interest in the Western world, where the slave trade and colonial powers could use the ideas to legitimate their actions.

In this type of intellectual climate migrations become a way to explain how one, for example, can find traces of highly advanced architecture in uncivilized cultures. Great Zimbabwe represents a good example of this 
mode of thinking. Because the white people in Rhodesia could not accept that black indigenous inhabitants had built it up, they used all sorts of migration hypotheses to explain the buildings. The preference was for theories that proposed that people from outside Africa erected the buildings - e.g. the Phoenicians, Arabs or Portuguese - and almost every theory was accepted as long as it did not include the natives (Adams et al. 1978:495). The colonialist's own culture (which included migrations) was used as an explanation. During that time one did not see any contradiction between theories of evolution and migration, and "Native societies were assumed to be static and evidence of change in the archaeological record, when noted, was attributed to migrations rather than to internal dynamism" (Trigger 1989:145).

These ideas were even more pronounced at the end of the $19^{\text {th }}$ century, when the social and economical problems in Western Europe started. The idea of a constant development and progression was questioned, as well as the idea that the same invention could arise at different places independent of each other. Consequently migration and diffusion gained ground as an explanation of change.

It is of interest that we in archaeology can distinguish from this epoch a difference in the use of the concept of "culture", which can be compared to the different views on mankind described above. Montelius, who despite his background in natural science was not very influenced by the Darwinians (Trigger 1989:157), thought that both diffusion and migration lay behind the spread of new technology from the Near East. Consequently, he did not see any obstacles for ideas to spread from one people to another.

Gustaf Kossinna, on the other hand, regarded "highly developed cultures" as expressions of biological superiority, and civilization could therefore not be spread by ideas but only by migrations. He maintained that the archaeological culture (that is the material culture) corresponded to a pre- historic people/race (Shennan 1987:366), "scharf umgrenzte archäologische Kulturprovinzen decken sich zu allen Zeiten mit ganz bestimmten Völkern oder Völkerstämmen" (Kossinna 1978:3). These ideas could be linked to the general debate, in which the biological approach was predominant. If one in earlier times had viewed race both as a cultural and a biological concept, the interest had now shifted to the biological approach - common culture presupposes a common descent (Liedman 1997:170). Childe's use of the concept "culture" is illustrative of the changes; in the beginning of his career he absorbed the German concept of culture, which was defined by distinctive pottery and as representing a people (Childe 1958:70). However, by 1950 the biological approach was gone: "Perhaps I should remind you at the outset that culture and race do not coincide. What distinguishes human progress from organic evolution is, in fact, just this: a human society can adopt an invention made by another society biologically quite unrelated to it..." (Childe 1950:1). However, Kossinna did not seem to have any doubts about which culture was most highly developed, and the German region was consequently viewed as the centre for the cultural development. In this region of northern Europe the Germans had kept their pureness and were not mixed with other peoples, and thus they were conceived of as superior to others (Adams et al. 1978:493; Trigger 1989:166). But one should note that Montelius as well talked about an unmixed race in the Nordic countries (see below).

It is here possible to see how different the theoretical approaches could be when using migration as an explanation for cultural change. The more "open" standpoint views migration as something which promotes development, and does not see any obstacles for this to spread to other cultures. The other approach considers migration as the only way to erase primitiveness, and that one should not mix different peoples/races because they 
are biologically different. But one should not forget that even the more "positive" approach had disastrous consequences for many people, because the development was obviously meant to follow in Europe's footsteps.

\section{MOTHER OF NATIONS}

"The Swedes' journeys went mainly to the east and were directed towards tribes - Baltic, Finnish and Slavic - which in all respects remained at a lower stage of evolution than themselves. [...] The Swedes' task was to create order and organization in the eastern societies, culminating in the great enterprise of founding the Russian state" (Nerman 1942:248f).

The above quotation, and not least the title of Birger Nerman's book Sveriges första storhetstid (1942, "Sweden's first period of greatness", my transl.), illustrates how archaeology reflects nationalistic ideas of the time. The migrations described here involve people from Sweden and Gotland on their triumphal journeys in the east. The link to the contemporary debate can be detected in the language: we can read about Swedish colonies and "the time of the great conquests". Nerman's ideas have their origin in a hierarchic approach to culture, where the "higher" culture brings order to the less successful.

In the early part of the $20^{\text {th }}$ century, Knut Stjerna wrote about emigrants from Sweden, who in large numbers wandered south and further into the Roman Empire in AD 300500 . The conclusions are drawn from written as well as archaeological sources, and we are told that the latter indicates a decrease in population density and even depopulation (Stjerna 1905). Sune Lindqvist agrees on the migrations, but he maintains that the movement's directions are misinterpreted, because Stjerna did not take the sources from the Continent into consideration. In Lindqvist's account we can, on the other hand, read about the return of whole tribes and groups of warriors (Lindqvist 1922:185).
Such a dispute is typical for the migration debate in archaeology during this period; one did not question migration as such, and neither did one in any depth discuss the causes and the implications for society, but rather, the interest was completely focused on the directions of the migrations. The equation between the material culture (and foremost the style) and a people is obvious.

In this traditional archaeology, the migrations that are described are almost without exception the movements of an entire people, and one often talks about "waves" that "surge" through the landscape (e.g. Lindqvist 1918:79), which makes us associate to a huge mass of people. Such expressions, which I think are unfortunate if we really want to understand migrations, are not only typical of the early $20^{\text {th }}$ century. They also occur frequently in Dick Harrison's work from 1999 on the European Migration period. "In different waves, one after another, tribes of nomads could stream in like tidal waves..." (Harrison 1999:36, my trans1.). The vocabulary is borrowed from a military context, and the association with water makes it seem like the "old people" were drowning or were swept away and the land was "cleaned". Childe's interpretations in The Dawn of European Civilization are, in his own view, an attempt to rewrite such a politico-military history and replace battles with migrations (Childe 1925:70).

Another thing that is clearly visible in the archaeology of the early $20^{\text {th }}$ century is the biological approach, where one does not distinguish among people, culture and race, and the discussion often takes its departure in physical anthropology. It is true that Sune Lindqvist mentions that several studies have revealed that anthropological and archaeological research have come to opposite conclusions, but he himself nevertheless maintains that human crania could be used to support (or not to support) occasional migrations (Lindqvist 1918:83f). Nils-Gustaf Gejvall had objections to this, and his opinion is 
that the crania, in spite of the differences, have been described as homogeneous. Gejvall himself claims that the sculls show great variance and indicate different origins, and he holds that people gradually and recurrently came to Scandinavia (Gejvall 1955:19f).

As we have seen above, it is not difficult to find nationalistic traits in the interpretations from this period. According to Stjerna, the Svear were the conquering people in the Migration period, and the reason for the silence in the written sources is that they were written by the enemies of the Svear (Stjerna 1905:347). In these early works it seems important to emphasize that the first settlers in Sweden actually were the contemporary population's ancestors. Oscar Montelius maintains that analyses of skeletal remains support this, and "ancestor" in this context presupposes a common race. The "longhead" race was mixed with "shortheads" on the Continent, but stayed unmixed in the Nordic countries: "Nowhere has this race kept its pureness as in Sweden and Norway" (Montelius 1919:14, my transl.; see also Montelius 1918:32). There is no doubt as to whom Montelius writes - the mere title of the work, Var forntid ("Our Prehistoric Past", my transl.) tells us that it directs itself to the Swedish people, and more than once it is stated that "we" are descendants of the first settlers. "It is consequently our people which settled the Swedish country" (ibid:71, italics in original, my transl.).

The immigrations to Scandinavia are, according to Montelius, the return to "the old home" by those who left earlier (Montelius 1918:21f, 1919:233). Lindqvist also talks about tribes that return (see above), which implies that it is not a different people (or race) who comes to Scandinavia, even if the sources indicate immigration. Such an interpretation is essential if one wants to see the Nordic people as pure from "foreign" in-

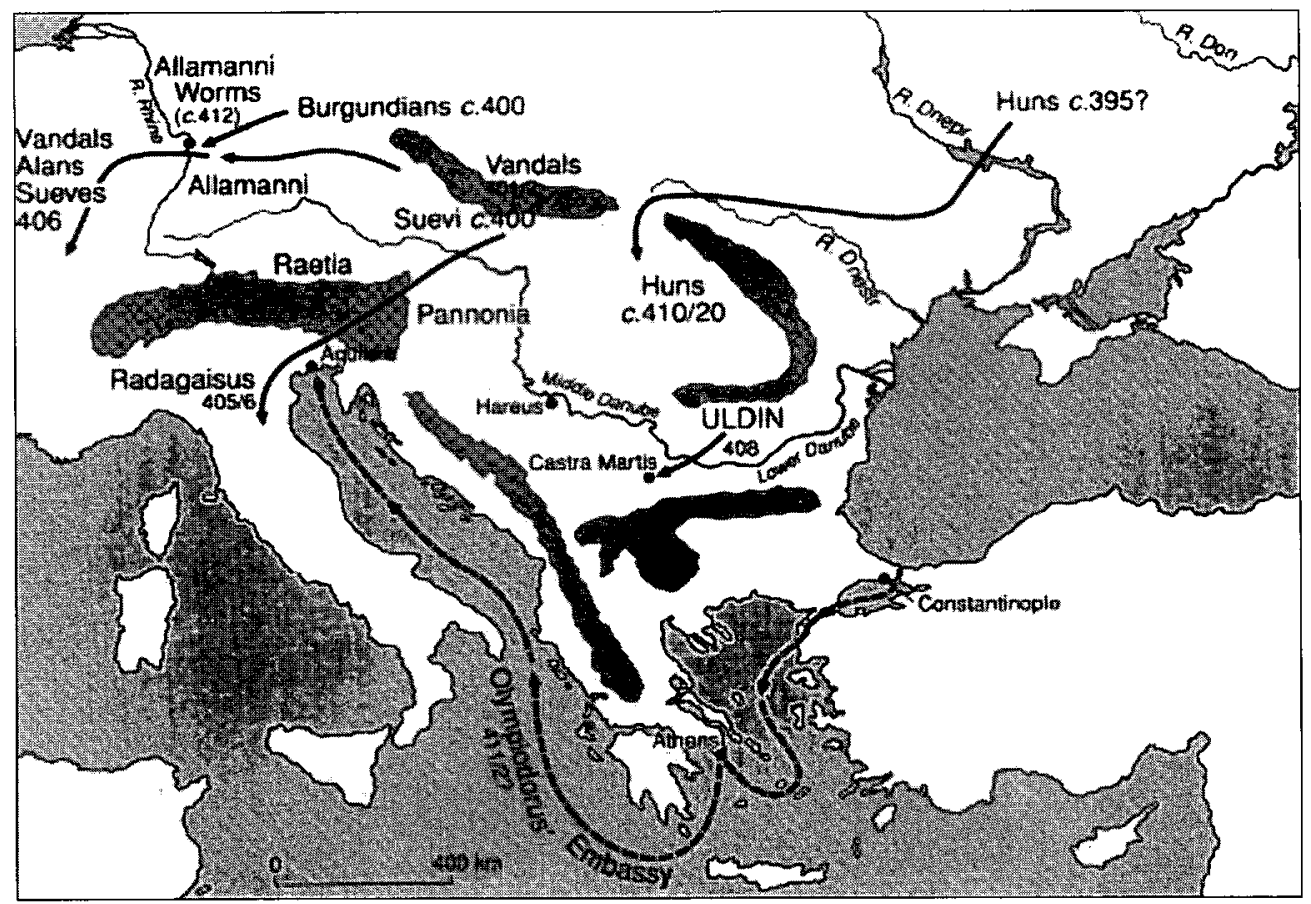

Fig. 2. Maps such as this are often used to illustrate different people's movements across the European continent. This one illustrates the consequences of the arrival of the Huns in the beginning of the $5^{\text {th }}$ century (Heather 1998:105). 
fluence, but it is hard to see that the archaeological sources really support the idea that it was "the same people" who returned.

One example of a much debated migration is the wanderings of the Goths across Europe. In Sweden they played a part in the nationalistic writings, as well as in other European countries, not least in Nazi Germany. In the Swedish royal coat of arms, the second of the three crowns lays claim to be the kingdom of the Goths - regnum Gothorum (Harrison 1999:32f; Heather 1998:2). As early as the $17^{\text {th }}$ century Olof Rudbeck created such a pro-Gothic vision, inspired by Jordanes' writings about Scandza as an "officina gentium aut certe velut vagina nationum - factory of tribes and surely a mother of nations" (Wolfram 1988:2). In a book from 1940, Sven Tunberg uses what he considers to be archaeological evidence to support the idea of the Goths' origin in Scandinavia. Here we find statements which clearly demonstrate the importance one attached to the cultural unity of Scandinavia. "The archaeological research of the last decades does not leave us in any doubt about the fact that the Nordic countries were settled and controlled by one and the same people, the Nordic-Germanic, since at least a couple of thousand years before Christ. This research also indicates that this Germanic people had been the sole possessor of the Nordic settlements, and thus had no competition from foreign people (Tunberg 1940:42, my transl.).

Accordingly, in the early $20^{\text {th }}$-century Swedish archaeology, migration theories were sometimes used in a nationalistic and chauvinistic way. In the examples one can observe an ideal of cultural and racial homogeneity, and an emphasis on the Swedish/ Nordic people's strength. At the time there was obviously nothing remarkable about such ideas, while it is hard to see their position in an academic discourse today. This illustrates how important it is with a debate within the archaeological discipline, where trends and "self-evident" facts are discussed. Of course, one can question whether archaeologists at the time were aware of the connections to the contemporary processes, but this is no reason for us to avoid such a debate today.

\section{THE POWER OF ACADEMIC TRADITION}

"In glaring contrast to ideas about the constant invasions of the British Isles, stands the Montelian image of the Swedish prehistory, with its continuous and intact population development since the Stone Age, and which again and again was the point of departure for expansion and emigrations across the sea" (Moberg 1955:13, my transl.).

Obviously, Swedish archaeologists did not have any problem with talking about migrations in the ancient past, but one should note that migrations foremost were thought to have affected other people. In this context CarlAxel Moberg holds an interesting discussion when he takes a closer look at how interpretations that involve migrations are constituted in different countries. He exemplifies with research in Sweden, which strongly emphasizes the continuity and mainly discusses emigrations, and contrast this with the British archaeology (Moberg 1955). In the latter one has, on the other hand, maintained that "what was biologically and culturally most desirable in successive indigenous populations had combined with what was most advanced in invading groups to produce a people whose hybrid vigour, composed of various European stocks, made them the best in the world" (Trigger 1989:168). Moberg questions whether this difference between interpretations in Scandinavian and British archaeology really could be justified by differences in the archaeological sources, and he is more inclined to think that the variations to a large extent are caused by divergences in the scholarly traditions.

It is also possible to find these tendencies in Scandinavian archaeology today, and one 
question is why the Scandinavian research has taken this position. The historical archives are certainly not without examples of immigrations: the Hanseatic influence in the Middle Ages, the Walloons in the $17^{\text {th }}$ century, the Romany with a start in the $16^{\text {th }}$ century, a royal family with French origin, and not least the labour migrations in the second half of the $20^{\text {th }}$ century, just to mention a few. Maybe this is paradoxically connected with the fact that Great Britain has a history as a colonial power, and that the English language is spread throughout the world, while the small Nordic countries uphold their culture and language with reference to a long continuity. Anyway, it is important to be observant in the future with regard to this characteristic in Scandinavian research.

\section{THE RETREAT FROM MIGRATIONISM}

"They [historical explanations such as migrations] add nothing to the explanation of the processes of cultural change and explanation" (Binford 1972:22).

It is hardly surprising that archaeologists dissociated themselves from theories of migration after the Second World War. The Nazi use of archaeology was alarming, and the general debate with its anti-colonialism and anti-imperialism had naturally an impact on the archaeological debate at the time (Kristiansen 1989:211ff). The theories changed, and when archaeology left the culturalhistorical approach and turned towards a functionalistic one, the opinions on migration theories changed as well. From the 1950s it is possible to distinguish a growing number of critical voices, and the New Archaeology implied a breakthrough of what is called "the Retreat from Migrationism" (Chapman 1997). "For many years, those who incorporated migration into explanations of culture change risked being associated with a form of interpretation that was regarded as normative, simplistic, unsupported by functionalist models of social evolution, and/or impossible to test objectively" (Anthony 1997:21). Migrations were not considered to be a relevant explanation, and Lewis Binford is of the opinion that migrations are not a sufficient explanation. Migration is itself a problem, which has to be explained in systemic terms, and like other changes it has to be studied as an adaptive and evolutionary process (Binford 1972:22).

As John Chapman (1997:12) has pointed out, this rejection of migrations is somewhat in contrast with the processual theory, in which the cultural system will change only with impulses from outside the system. It is hard to understand why migrations could not be accepted as generating change, even if one has to ask further questions when a migration is established. But instead of considering migrations as part of an understanding, they more or less disappeared from the archaeological discourse.

Again, we can see how Childe's works are an illustrative example of these changes. In his earlier work on Europe he focused on external events and saw migrations from the east as the cause of change, and the focus was the "irradiation" by Oriental and Aegean civilization (Childe 1925, 1958). In his last paper, written in 1957, his opinion had changed somewhat, and he now emphasized the internal and the specific European development (Childe 1958).

The debate in Sweden kept up well with the times, and as early as the 1950s the Swedish Archaeological Society initiated a debate about migrations. The purpose was to throw light on the topic from different angles, but above all to discuss when (and if) a source material can be interpreted as a result of migration. The introductory contributions were later published in Fornvännen (1955), where the archaeological contributions were written by Gutorm Gjessing and Carl-Axel Moberg, and the article on physical anthropology by Nils-Gustaf Gejvall. The reading of these papers leaves us with a rather pessimistic picture of the possibilities to 
discuss prehistoric migrations. In Gjessing's words: "this theoretical exposition has not been particularly encouraging when it comes to finding certain proof of movements in archaeology. This is because the reliable criteria do not come from the archaeological sources..." (Gjessing 1955:9, my transl.). Moberg as well stresses the uncertainty in migration theory (Moberg 1955:18).

I think this is one of the reasons for the archaeological discipline's lack of interest in migrations, especially if we compare with other social sciences. In our discipline one tends to get stuck on the question of whether a migration really happened, and that is why it is difficult to go on to questions which certainly could be interesting: what happens with culture when people move, who is migrating and what are the reasons, how are migrations valued, and what stories and myths are connected with them? An important question for the future (and which probably is necessary if the topic shall generate stimulating research) is what we can do to leave this dead end.

The archaeological pessimism about the possibilities to study migrations in the past is also dependent on the fact that the cultural concept has been widened, and that it is much more complex today. This is a broad field of discussion, and I will confine myself to a few comments. The fact that researchers in traditional archaeology did not have such a problematic relation to migrations is probably due to their approach to culture, with a relatively simple connection between material culture and people. When the concept of culture became more complex and nuanced, it was not as easy to connect changes in the archaeological material to migrations.

One of the problems is that culture is not only characterized by the material reality, but also by people's ideas of identity. In 1972 Bente Magnus Myhre and Bjørn Myhre wrote an article in Norwegian Archaeological Review, in which they discuss how this will influence interpretations of migrations: "If what characterizes a culture is the ideas it contains and not its material remains, how can the archaeologist know whether his culture is something he has himself made up or something which reflects actual conditions? Archaeologists lack knowledge of too many of the essential features of a culture and are apt to sound large conclusions on scanty material" (Magnus Myhre \& Myhre 1972:46). They scrutinize some interpretations and find that the material does not support migration hypothesis in these cases. Their somewhat discouraging conclusion is that it is difficult to find a general definition for the concept of migration, and that it therefore "must be questioned whether it is in any way profitable to discuss or employ the concept immigration in a purely prehistoric context" (ibid:61).

The paper refers, among other things, to Mats Malmer's work on the Neolithic "Battle Axe culture" (Malmer 1962), whose rapid appearance has often have been interpreted as the result of a migration. Malmer questions this interpretation, and he discusses whether it is at all possible to prove a migration in the archaeological material. For this purpose he presents two methods - one direct and one indirect. The direct method relies on physical anthropology, and it tries to determine whether a population's physical racial characteristics have changed. As we have seen earlier, this method has often been considered as problematic (see also Magnus Myhre \& Myhre 1972:47). The indirect method deals with the material culture and can be divided into four parts (Malmer 1962:807). Because the fourth factor - which implies that you have to find an "exact analogy" with the immigration you want to verify - is impossible as far as I can see, migrations can not be identified in this way.

The fact that it has not been popular to speak of migrations in Swedish archaeology, can also be exemplified by the changes instigated by Göran Burenhult in the translation of Bra Böckers Världshistoria ("The History 


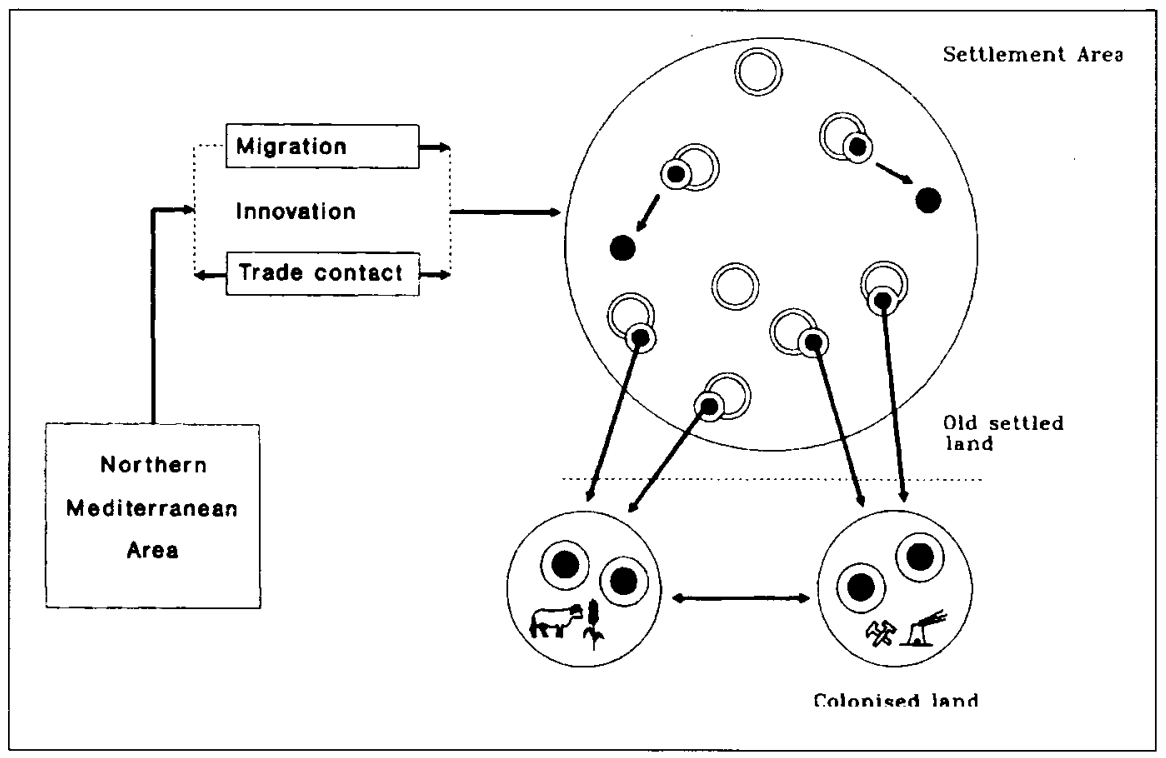

Fig. 3. Different systemic models are also used to illustrate migrations. This is a model of later La Tène colonisation in Central Europe, from Kristiansen 1998:339.

of the World"). A whole chapter has been replaced, and the migrations, which the authors Randi and Gunnar Håland regarded as an important part of Europe's history, are gone (Welinder 1985).

\section{MIGRATION - ONCE AGAIN ON THE ARCHAEOLOGICAL AGENDA}

"Since diffusion and migrations were among the most criticised explanatory concepts of so-called traditional archaeology; modern archaeology has not yet come to terms with them, either in archaeological or in theoretical terms" (Kristiansen 1998:314).

In the 1990 s one can see how migrations have returned as a topic of discussion, or as Clive Gamble puts it: "Migration and diffusion are back in town" (1993:37). He regards Colin Renfrew's book Archaeology and Language from 1987 as a starting point for this renewed interest. Here Renfrew states that migrations have been replaced by other, more complex, explanations for cultural change. But he also asks whether this means that archaeology has "thrown the baby out with the bathwater" (Renfrew 1987:3), an expression that has followed much of the debate since then (e.g. Anthony 1990; Chapman \& Dolukhanov 1992).

The conclusion that migration is a current question can also be drawn from the fact that a volume of B.A.R. is dedicated to migrations (Chapman, J \& Hamerow 1997). It is here argued that it was New Archaeology which "demonized" and removed migrations from the archaeological debate, while the postprocessual archaeology has been open to such ideas (Anthony 1997; Chapman 1997). I am not sure that I have seen such tendencies. In the early post-processual archaeology the focus was on interpretations that considered internal developments, and a discussion about migrations was not at the top of the list. It is in the last decade that migrations have become more common in archaeological research, and certainly not only in postprocessual archaeology. I can not see that the study of migrations is associated with a 
particular theoretical approach today, but rather, the interest comes from different directions. In line with processual theories, one tries to find general principles to identify traces of migrations (e.g. Anthony 1990:909), while the post-processuals discuss the consequences and possible conflicts which can follow migrations (Olsen 1997:168).

Kristian Kristiansen has criticized the archaeologists' lack of interest in migrations, and he holds that our understanding of cultural and social change will be distorted if we do not take migrations into consideration (Kristiansen 1989:121, 1998:314ff). He claims that the study of migrations has to be contextual, that the historical background must be considered, and finally, that the migration has to be put in a broader framework. In the study he holds that the rise of the Single Grave Culture in Denmark represents a classic example of migration (Kristiansen 1989:214), an interpretation which has been questioned by Charlotte Damm (1991). Here the archaeological dilemma is once again evident - the question of whether a migration really happened prevents us from going on to other interesting questions.

There are other problems which characterized the earlier research, and which tend to accompany the debate today as well. One such problem is the question of cultural identity or ethnicity, both of which are concepts closely related to migration studies. In Scandinavian Iron Age studies it is quite common to talk about a Germanic identity. One example is Lotte Hedeager, who has written a great deal about migrations in Iron Age Europe (e.g. Hedeager 1992, 1993), and whose discussion centers on a common "Germanic identity". But what actually constitutes the "Germanic"? Hedeager speaks of how "the Germanic national armies came drifting southwards" in the Roman Iron Age, groups that differ and have changed from the earlier "traditional Germanic tribal communities" (Hedeager 1993:123). Is it the language which unites these different "Germanic" societies, or what is the common denominator? Several scholars today are debating and questioning the use of such concepts as Celts or Germans (e.g. Chapman 1992; Näsman 1999; Pohl 1998). One reason is that the classification of the "barbaric people" was done from the Roman side, and it is uncertain whether these people saw themselves in such a way. "Thus the distinction between Celts and Germans at the time that the latter are first named cannot be regarded as an ethnic one in any sense. Both are names given by outsiders to designate large groupings that did not exist in the minds of those so designated" (Wells 1995:181). Consequently it is essential to discuss concepts like cultural identity and ethnicity when one studies migrations.

The revival of interest in many questions from the traditional archaeology is exemplified by the debate on what migration studies can learn from physical anthropology. In a study of burials from $5^{\text {th }}$ - and $6^{\text {th }}$-century England, Heinrich Härke has seen a connection between specific artefacts and peculiarities in the skeletal remains. Individuals buried with weapons were $2-5 \mathrm{~cm}$ taller in comparison with others, and Härke's conclusion is that the deceased in the weapon graves were Anglo-Saxon immigrants (Härke 1990, 1992). In line with this, the combination of artefacts and skeletal remains should support an interpretation of migration.

A summary view of the archaeological "trends", such as the one in this paper, gives of course a simplified picture. Migration has been used to explain cultural differences and changes during "the retreat from migration" as well, especially when it comes to certain questions. The debate about immigrations to northern Scandinavia is one such example.

Evert Baudou is among the archaeologists who consider migrations as a probable explanation for many changes in the prehistory of northern Sweden (Baudou 1995). Here it is of interest that the diffusion of the material 
culture is interpreted in different ways. The burial cairns along the coast are assumed to be the result of a migration from the south of Sweden (ibid:100ff). The influence from the south is thus interpreted as immigration, but for some reason this is not the case with the influences from the east. Despite the fact that in the Early Bronze Age one "took over" a whole assemblage of artefacts from the east, this is not interpreted as immigration but as a diffusion of ideas and techniques (ibid:95). The reason for the differences in interpretation is not clear, but perhaps it is related to the wish to see the population in northern Sweden as the Swedish people's ancestors (ibid:112).

\section{MIGRATIONS AND THE GENERAL DEBATE}

In the discussion about the current interest in migrations, one has studied the connection to the general debate of the time. In Clive Gamble's opinion, the fact that the question of migration has come up again is related to our uncertain times, and that it is "...an appeal to the Palaeolithic ancestors to show an underlying community of tradition that transcends the old east/west, rich/poor division" (Gamble 1993:38).

John Chapman, on the other hand, sees a connection between the retreat from migrationism and the fact that the younger generation did not have any experience of mass movements such as the one during and after the world wars. "It is not a coincidence, I believe, that the 'Retreat from Migrationism' arose precisely in countries not invaded in either world war - in Britain, America and parts of Scandinavia" (Chapman 1997:18). That the question has arisen again is due to changes in the refugee movements at the end of the 1980s (ibid:17f). I must admit that I do not find this explanation plausible. For one thing, the doubt about migrations in archaeology was present in Norway as well (Magnus Myhre \& Myhre 1972), a country which was occupied by the Germans in the
Second World War. Secondly, it seems unlikely to me that the avoidance of debating migrations in prehistory should be due to an ignorance of people's movements - in Sweden we had during these years a large labour-immigration, which was hardly invisible in the society. If anything, I believe that the somewhat contradictory picture - to ignore migrations in prehistory at a time when mobility in the world increased and the media had the means to show it - is largely caused by a reaction against the older research and by the dissociation from colonialism and imperialism.

As I have mentioned earlier in this paper, I do not think one should carry this question too far; the history of ideas within a discipline has no doubt its own "logic". It has been suggested that the lack of interest in migrations is simply because archaeology is not suited to the study of migrations, even if they have occurred. David Anthony maintains that most archaeologists agree that migrations could have an important role in cultural change, but that our discipline lacks the theories and methods to study them (Anthony 1990:895). That the question has arisen again is because one has realised the significance of migrations for many processes in history (ibid:897).

\section{AND THE FUTURE...}

"The study of migration has two aspects: to determine whether migrations have occurred at a certain period or not, and if they have, to locate the area of emigration" (Gjessing 1972:62).

If one limits the study of migration to these two questions, it is not surprising that it seems like a question from another time. Many archaeologists express scepticism towards the entire debate today. There is some exaggeration in the polemic against those who talk about migrations, in that they are viewed as always explaining change and new artefacts with migrations. But migrations need not be 
a mechanical explanation for every change, but a part of the discussion about cultural variation and identity. If the movements of people, with immigrations, emigrations and the cultural meetings that follow, are part of our history, I will argue that we cannot just drop the question. What interest in the society of today are we supporting if we deny that people's movements are part of our (pre)history? Like other questions which sometimes have been considered impossible for the archaeologist to study (culture and religion for instance), the theories of today ought to be able to bring new ideas into the study of migration.

We often demand clear definitions of the concepts we use, and we must of course discuss them explicitly. But with too narrow definitions of some concepts, we can not see their common associations or the questions they generate. Instead of looking for a general and clear definition of migration, or categorizing different types of movements, we should focus on the meetings between different cultures and the traditions

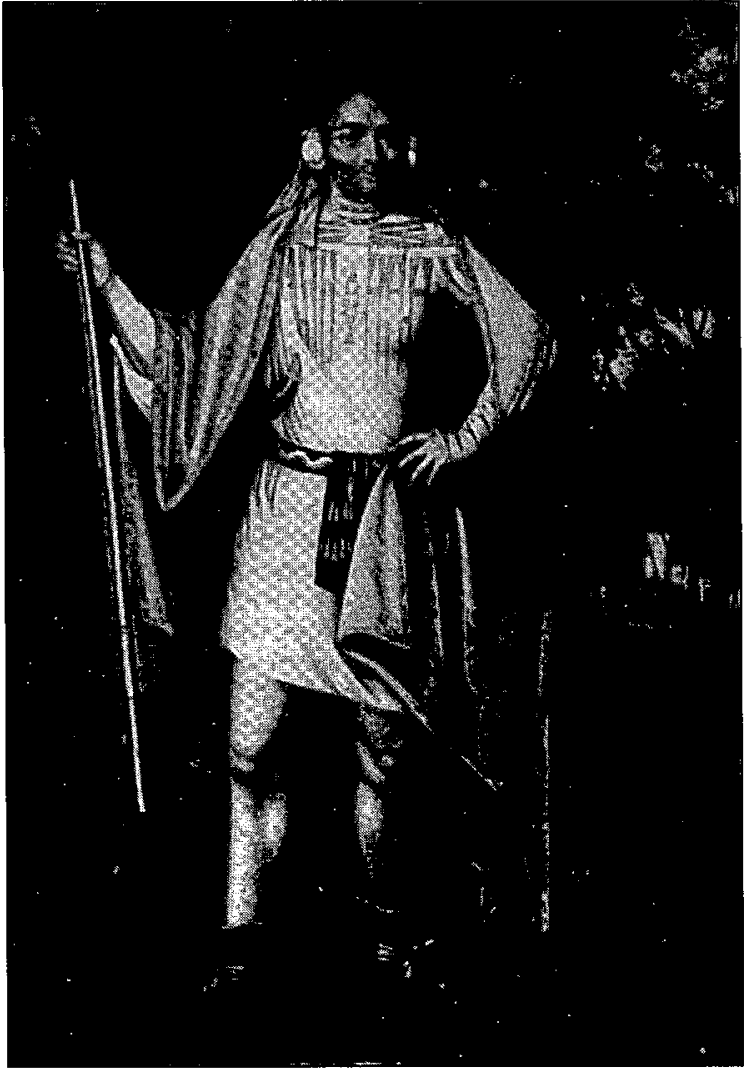

Fig. 4. Portrait of a Mohawk chief fiom 1710. The dress illustrates the European influence on the Iroquois by this time (Middleton 1992:304). which they lead to. The Roman expansion over the world did not only result in a "Romanization" of other cultures - no, the meetings also changed what constituted "the Roman". In the same way refugees are not only assimilated in their new culture, but also have an influence over it. In such a discourse the somewhat blurred concept of "migration" has a place, where it is precisely its broad signification which gives us a lot of associations, which in turn enrich our understanding.

But if the migration debate is on its way back, we have to make sure that we do not simply "re-cycle" the traditional archaeology's approaches to migration. We have to ask new questions if the study shall be meaningful at all. One starting-point could be the stimulating debate on culture and ethnicity, which is of immediate interest not least concerning the "post-Roman" Europe (see e.g. Pohl 1998). The migrations led to encounters between different cultures; and how did such meetings influence the societies? It is not as simple as taking a "little from each", on the contrary: "Both parties will have to modify their cultures; but since a structure is always more than the sum of its parts, such modifications will lead not to a mechanical mixing but to new forms" (Magnus Myhre \& Myhre 1972:48). In these questions we have a source of inspiration in the works on colonialism and post- 
colonialism, which is a major topic in social science and history today (e.g. Bitterli 1989; Clifford 1992; Gandhi 1998; Thomas 1991).

Another area of interest is the myths of origin, which often include a migration as an important part; "Migration theory in a sense is as old as tribal mythology; indeed, it is a rare corpus of myth that does not include at least one migration episode" (Adams et al. 1978:483). Instead of arguing that these wanderings have not really occurred, the myths have a lot to offer if one wants to understand the creation and maintenance of a cultural identity (Eriksen 1993; Howe 1989).

In the article "The End of What? Archaeology and the Politics of Identity in a Globalized World", Bjørnar Olsen discusses what role archaeology has in today's changing society. Archaeologists have considered it their task (and still do) to write a history about a common and homogeneous national or European past and about continuity through time - a project that is supposed to give people a common identity by means of their past. "It is this $19^{\text {th }}$ century desire for origin, to construct the past as linear narratives of continuity and repetition, which currently serves as the fundament for essentialist identity projects and associated histories of revenge "(Olsen in press). Instead of presenting a picture of the past that resembles life today, we could point towards the differences. Here, the archaeology of migrations could have an important part, since the past is full of examples of how people move, change and assimilate - and history shows that culture is a mixture of different influences and that it is constantly changing. The "plural societies" with cultural diversity is not a (post-)modern phenomenon (Jenkins 1997 chapter 3), and Europe in the first millennium A.D. is a good example of this. A "pure" and bounded culture does not exist, and instead of looking for something common and typically Swedish, Nordic,
European or "Germanic" in our past, archaeology could show how winding and unexpected the road was towards the creation of what today is called the Swedish culture. And we will hardly find its origins in a distant past.

One of the favourite symbols of the neoNazis, the Vikings, is a telling example from the past. The Vikings were not afraid of the foreign and the strange, and their ambition was obviously not to keep their culture pure - instead they were travelling, intermarrying with other peoples, changing their language and assimilating in their new worlds.

In the essay "Imaginary Homelands" (1992), the author Salman Rushdie discusses the situation of the exiles. How can a culture survive without becoming static, and how does one behave towards the new culture? Living as an immigrant is connected with many problems - the feeling of falling between two stools is one - but it gives access to a somewhat different perspective as well. "America, a nation of immigrants, has created great literature out of the phenomenon of cultural transplantation, out of examining the ways in which people cope with a new world" (Rushdie 1992:20). For the archaeologist who is struggling with the concepts of culture, this might be one way to proceed; maybe we should try to put ourselves "between" different cultural traditions and see what is happening there. And migrations could be one point of departure for such studies.

\section{English revised by Laura Wrang.}

\section{ACKNOWLEDGEMENTS}

I would like to thank Berit Wallenbergs Stiftelse who made it possible to begin with a project on migrations, and HumanistiskSamhällsvetenskapliga Forskningsrådet who funded my research during a visit at the Institute of Archaeology, University of Tromsø. 


\section{REFERENCES}

Adams, W. Y. et al. 1978. The Retreat from Migrationism. Annual Review of Anthropology. Vol 7. Pp. 483-532.

Anthony, D. 1990. Migration in Archaeology: The Baby and the Bathwater. American Anthropologist. Vol 92. No 3. Pp. 895-914.

- 1997. Prehistoric Migration as Social Process. In: Chapman, J. \& Hamerow, H. (Eds). Migrations and Invasions in Archaeological Explanation. BAR International Series 664. Pp. 21-32. Oxford.

Baudou, E. 1995. Norrlands forntid: ett historiskt perspektiv. Wiken.

Einford, L. R. 1972. An archaeological perspective. New York.

Bitterli, U. 1989. Cultures in conflict: encounters between European and non-European cultures, 1492-1800. Cambridge.

Chapman, J. 1997. The impact of Modern Invasions and Migrations on Archaeological Explanation. In: Chapman, J. \& Hamerow, H. (Eds). Migrations and Invasions in Archaeological Explanation. BAR International Series 664. Pp. 11-20. Oxford.

Chapman, J. \& Dolukhanov, P. M. 1992. The Baby and the Bathwater: Pulling the Plug on Migrations. American Anthropologist. Vol 94. No 1. Pp. 169-174.

Chapman, J. \& Hamerow, H. 1997. (Eds). Migrations and Invasions in Archaeological Explanation. BAR International Series 664. Oxford.

Chapman, M. 1992. The Celts. The Construction of a Myth. New York.

Childe, V. G. 1925. The Dawn of European Civilization. London.

- 1950. Prehistoric Migrations in Europe. Oslo.

- 1958. Retrospect. Antiquity. Vol. 32. Pp. 6974.

Clifford, J. 1992. Traveling Cultures. In: Grossberg, L. et al. (Eds). Cultural Studies. Pp. 96116. London, New York.

Cohen, R. (Ed). 1996. Theories of Migration. The international library of studies on migration. Cheltenham.

Damm, C. 1991. The Danish Single Grave Culture - Ethnic Migration or Social Construction. Journal of Danish Archaeology. Vol 10. Pp. 199-204.

Eriksen, E. 1996. Arkeologers søken etter de første menneske i Norge. Et forskningshistorisk til- bakeblikk. Hovedfagsavhandling. Tromsø.

Eriksen, T. H. 1993 Ethnicity and Nationalism. Anthropological Perspectives. London.

Fornvännen. 1955. Redaktionens inledning till "Vittnesbörd om folkvandringar". P. 1.

Gamble, C. 1993. People on the Move: Interpretations of Regional Variation in Palaeolithic Europe. In: Chapman, J. \& Dolukhanov, P. (Eds). Cultural Transformations and Interactions in Eastern Europe. Pp. 37-55. Avebury, Aldershot.

Gandhi, L. 1998. Postcolonial theory: a critical introduction. New York.

Gejvall, N-G. 1955. Vittnesbörd om folkvandringar. Diskussionsinledning. Fornvännen. Pp. 19-21.

Gjessing, G. 1955. Vittnesbörd om folkvandringar. Diskussionsinledning. Fornvännen. Pp. $1-10$.

- 1972. Comments on Immigration in Archaeological Contexts. Norwegian Archaeological Review 5:1. Pp. 61-63.

Harrison, D. 1999. Krigarnas och helgonens tid: Västeuropas historia 400-800 e.Kr. Stockholm.

Heather, P. 1998. The Goths. Oxford.

Hedeager, L. 1992. Kingdoms, Ethnicity and Material Culture: Denmark in a European Perspective. In: Carver, M. (Ed). The Age of Sutton Hoo: the seventh century in northwestern Europe. Pp. 279-300. The Boydell Press, Woodbridge.

1993. The Creation of Germanic Identity. A European Origin-Myth. In: Brun, P. et al. (Eds). Frontières d'empire. Nature et signification des frontières romaines. Pp. 121131. Nemours.

Helms, M. 1998. Ulysses' Sail. An Ethnographic Odyssey of Power, Knowledge, and Geographical Distance. Princeton University Press.

Howe, N. 1989. Migration and Mythmaking in Anglo-Saxon England. New Haven.

Härke, H. 1990. "Warrior Graves"? The Background of the Anglo-Saxon Weapon Burial Rite. Past and Present 126. Pp. 22-43.

- 1992. Changing Symbols in a Changing Society: The Anglo-Saxon Weapon Burial Rite in the Seventh Century. In: Carver, M. (Ed). The Age of Sutton Hoo: the seventh 
century in north-western Europe. Woodbridge.

ILO Convention 169. ftp://ftp.halcyon.com/pub/ FWDP/International/ilo_169.txt

Jenkins, R. 1997. Rethinking Ethnicity. Arguments and Explorations. London.

Jones, S. 1997. The archaeology of ethnicity. Construction identities in the past and present. London.

Kasdan, L. 1970. Introduction. In: Spencer, R. F. (Ed). Migration and Anthropology. Pp. 1-6. University of Washington Press.

Kossinna, Gustaf. 1978 [1911]. Die Herkunft der Germanen. Bonn.

Kristiansen, K. 1989. Prehistoric Migrations - the Case of the Single Grave and Corded Ware Cultures. Journal of Danish Archaeology. Vol 8. Pp. 211-225.

- 1998. Europe before history. Cambridge University Press.

Liedman, S-E. 1997. I skuggan av framtiden. Modernitetens idéhistoria. Stockholm.

Lindqvist, S. 1918. Nordens benålder och en teori om dess stenåldersraser. $R I G$. Pp. 65-84

- 1922. Till vår folkvandringstids historia. Fornvännen. Pp. 166-188.

Magnus Myhre, B. \& Myhre, B. 1972. The Concept 'Immigration' in Archaeological Contexts Illustrated by Examples from West Norwegian and North Norwegian Early Iron Age. Norwegian Archaeological Review 5:1. Pp. 45-61.

Malmer, M. P. 1962. Jungneolithische Studien. Acta Archaeologica Lundensia, Ser. in $8^{\circ}$. $\mathrm{N}^{\circ} 2$. Lund.

Middleton, R. 1992. Colonial America. A History, 1607-1760. Cambridge, Massachusetts.

Moberg, C-A. 1955. Vittnesbörd om folkvandringar. Diskussionsinledning. Fornvännen. Pp. 10-19.

Montelius, O. 1918. Germanernas hem. Stockholm.

- 1919. Vär forntid. Stockholm.

Nerman, B. 1942. Sveriges första storhetstid. Stockholm.

Näsman, U. 1999. Hjaelp, germanerne kommer! In: Fuglestvedt, l. et al. (Eds). Et hus med mange rom. Vennebok till Bjorn Myhre på 60 årsdagen. Bind A. Pp. 163-173. Stavanger.

Olsen, B. 1997. Fra ting til tekst. Teoretiske perspektiv $i$ arkeologisk forskning. Oslo.
- in press. The End of What? Archaeology and the Politics of Identity in a Globalized World. In: Layton, R. et al. (Eds). The Destruction and Conservation of Cultural Property. London.

Oxenstierna, E. 1948. Die Urheimat der Goten. Leipzig, Stockholm.

Petersen, W. 1996. A General Typology of Migration. In: Cohen, R. (Ed). Theories of Migration. The international library of studies on migration. Pp. 3-13. Cheltenham.

Pohl, W. 1998. Strategies of Distinction. The Construction of Ethnic Communities, 300 800. Leiden.

Rawick, G. P. 1970. West African Culture and North American Slavery: A Study of Culture Change among American Slaves in the AnteBellum South with Focus upon Slave Religion. In: Spencer, R. F. (Ed). Migration and Anthropology. Pp. 149-164. University of Washington Press.

Renfrew, C. 1987. Archaeology and Language. The Puzzle of Indo-European Origins. London

Richmond, A. H. 1996. Sociological Theories of International Migration: The Case of Refugees. In: Cohen, R. (Ed). The Sociology of Migration. The international library of studies on migration. Pp. 331-349. Cheltenham.

Rushdie, S. 1992. Imaginary Homelands. London. Shennan, S. 1987. Trends in the Study of Later European Prehistory. In: Annual Review of Anthropology. Vol 16. Pp. 365-382.

Stjerna, K. 1905. Svear och Götar under folkvandringstiden. Svenska Fornminnesföreningens tidskrift. Band 12. Pp. 339-360.

Thomas, N. 1991. Entangled Objects. Exchange, Material Culture, and Colonialism in the Pacific. Cambridge, Massachusetts.

Trigger, B. 1989. A History of Archaeological Thought. Cambridge University Press.

Tunberg, S. 1940. Götarnas rike. Stockholm.

Welinder, S. 1985 Recension av Bra Böckers världshistoria. Band 1. Fornvännen. Pp. 241 242.

Wells, P. S. 1995. Identities, material culture, and change: 'Celts' and 'Germans' in late-IronAge Europe. Journal of European Archaeology. Vol 3:2. Pp. 169-185.

Wolfram, H. 1988. History of the Goths. University of California Press. 
